\title{
The Brāhmī inscriptions of Mongolia: Whose decipherment?
}

This short note serves the purpose of setting the record of the decipherment of the Mongolian Khüis Tolgoi and Bugut inscriptions straight.

Until recently, the Brāhmī inscriptions on the Khüis Tolgoi and Bugut stelae in Mongolia remained undeciphered, and any knowledge concerning the language in which they were written had been lost centuries ago. Finally, in the 20oos, Dieter Maue, an epigraphist and a leading specialist on the Brāhmī script, made a new reading of the inscriptions, allowing, for the first time, the question concerning the underlying language to be approached in a meaningful way. Then, the French historian Étienne de La Vaissière invited Alexander Vovin, during the latter's visit to Paris, to have a look at Maue's reading of the Khüis Tolgoi inscription. Vovin recognized the language as Mongolic, but there were still too many unidentifiable words and grammatical forms to allow for a complete translation. In 2014, an international team consisting of Dieter Maue (Germany), Alexander Vovin (USA, then already permanently working in France), Mehmet Ölmez (Turkey), and Étienne de La Vaissière (France) was formed, and the group travelled to Mongolia, accompanied by two specialists in $3 \mathrm{D}$ photography with the relevant instruments for taking $3^{\mathrm{D}}$ pictures. The principal objective was to document the inscriptions as completely as possible.

The team surveyed the inscriptions and took $3^{\mathrm{D}}$ pictures of the Khüis Tolgoi I and Brāhmī Bugut inscriptions, but could not do the same with Khüis Tolgoi II due to circumstances beyond the team's control. For more details on the team's travel to Mongolia, see Ölmez (2018). After the survey, Dieter Maue revised his epigraphic analysis and Alexander Vovin offered a first linguistic analysis and interpretation of the texts. The results were reported at the 6oth Permanent International Altaistic Conference (PIAC) at Székesfehérvár, Hungary, on August 31 - September 1, 2017. Then, draft versions were placed on the internet (Maue \& Ölmez 2017, Vovin 2017). After receiving the feedback from many internationally renowned Mongolists, the results of this discovery were published in the Journal Asiatique in 2018 (Ölmez 2018, Maue 2018, Vovin 2018, de La Vaissière 2018). The team's results on the Brāhmī Bugut inscription were published in the next issue of the Journal Asiatique (Ölmez 2019, Maue 2019, Vovin 2019a), followed by a more detailed description of the phonology, 
grammar, and lexicon of the underlying language, including a tentative translation of the Brāhmì Bugut, Khüis Tolgoi and two very short Keregentas inscriptions in the same language from eastern Kazakhstan (Vovin 2019b).

Sometime in late 2017 or early 2018, L. Qurčabayatur Solongyod (Hurcabaatar Solonggod), a German citizen originally from Ordos, Inner Mongolia, but currently engaged in hotel business in Cologne, Germany, who got his $\mathrm{PhD}$ degree from the University of Tübingen with a thesis on the cult of Chinggis Khan (published in Japan in 2001), asked Alexander Vovin for access to his data, which was not granted. Even so, in July 2019 - after all the articles by the original team members had been published - Qurčabayatur came out with a book (in Mongolian) where he claimed to have "deciphered" all the three Brāhmī inscriptions: Khüis Tolgoi I and II, and Brāhmī Bugut. For an ethnographer with no background in palaeography or historical linguistics this would have been an unlikely achievement without access to the publications of Maue and Vovin. However, in his bibliography he refers only to the team's initial presentations at the 6oth PIAC without mentioning their work on the actual decipherment of the inscriptions. His discussion of Khüis Tolgoi II is based on older estampages, and he is apparently unaware of the two Keregentas inscriptions. In his "analysis", Qurčabayatur also underestimates the fact that the inscriptions were written in the context of the First Turkic Khaganate and, as a result, contain many Turkic elements. Although much still remains to be done until a full understanding of the inscriptions is obtained, time will show that his independent contribution to their interpretation is minimal. Most importantly, his claim of having been the "first" to decipher these inscriptions is false.

The most discouraging consequence of this sequence of events is that, on August 5, 2021, the Government of Mongolia awarded Qurčabayatur the high Order of the Polar Star. While the gesture of rewarding a scholar with an Inner Mongolian background should be welcomed in these days, when the People's Republic of China is increasing its pressure on the Mongols, the Mongolian Government clearly picked the wrong person - perhaps out of sheer ignorance. The international community of Mongolists cannot stay silent about this blatant violation of the standard rules concerning the proper recognition of research results.

José Andrés Alonso de la Fuente, Co-editor of JEAL Institute of Linguistics, Translation Studies and Hungarian Studies Jagellonian University, Kraków, Poland jose.delafuente@uj.edu.pl 
Ákos Bertalan Apatóczky, Chair, Department of Chinese Studies

Károli Gáspár University, Budapest, Hungary

aab@azsiaport.hu

Benjamin Brosig, Postdoctoral Researcher, Mongolic Languages

Universität Bern, Switzerland

benjamin.brosig@isw.unibe.ch

Marcel Erdal, Professor Emeritus of Turkology

Goethe Universität, Frankfurt a.M., Germany

merdal4@gmail.com

Stefan Georg, Apl. Professor für Altaische Sprach- und Kulturwissenschaft Rheinische Friedrich-Wilhelms-Universität Bonn, Germany stefan.georg@bn-online.net

Peter Golden, Professor Emeritus of History, Turkish and Middle Eastern Studies

Rutgers University, New Jersey, USA

peterbgolden@gmail.com

Juha Janhunen, Professor Emeritus of East Asian Languages and Cultures University of Helsinki, Finland asiemajeure@yahoo.com

Bayarma Khabtagaeva, Associate Professor of Altaic Studies University of Szeged, Hungary baiarma.khabtagaeva@gmail.com

Victor H. Mair, Professor of Chinese University of Pennsylvania, USA vmair@upenn.edu

Hans Nugteren

Akademie der Wissenschaften zu Göttingen

hans.nugteren@phil.uni-goettingen.de

Elisabetta Ragagnin, Associate Professor of Turkology and Mongolian Studies Ca' Foscari University, Venice, Italy betta@vanmeel.org 
András Róna-Tas, Academician, Professor Emeritus of Altaic Studies

University of Szeged, Hungary

aronatas3@t-online.hu

William Rozycki, Outreach Coordinator

East Asian Studies Center

Indiana University

roz34zz@gmail.com

Pavel Rykin, Senior Research Fellow, Mongolian Studies

Institute for Linguistic Studies, Russian Academy of Sciences, St. Petersburg pavryk@yandex.ru

Zayabaatar Dalai, Professor, Dean, Director

School of Arts and Sciences, Institute for Mongol Studies National University of Mongolia

zayabaatar@num.edu.mn/zayabaatard@gmail.com

\section{References}

La Vaissière, Étienne de. 2018. The Historical Context to the Khüis Tolgoi Inscription. Journal Asiatique 306 (2): 315-319.

Maue, Dieter \& Mehmet Ölmez. 2017. The Khüis Tolgoi Inscription. https://www .academia.edu/40148067/The_Khu_is_Tolgoi_inscription.

Maue, Dieter. 2018. Signs and Sounds. Journal Asiatique 306 (2): 291-301.

Maue, Dieter. 2019. The Brāhmī Script on the Bugut Stele. Journal Asiatique 307 (1): 109-119.

Ölmez, Mehmet. 2018. The Khüis Tolgoi Inscription: On the Discovery, Whereabouts, Condition of the Stones, and an On-the-spot Visit. Journal Asiatique 306 (2): $287-289$.

Ölmez, Mehmet. 2019. A Short History of the Bugut Inscription. Journal Asiatique 307 (1): 91-96.

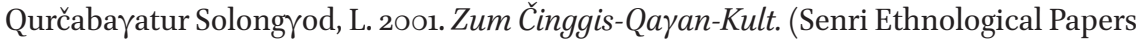
11.) Osaka: National Museum of Ethnology.

Qurčabayatur Solongrod, L. [Qurcabaqhadur Suluvgqhut] 2019. 1400 jil uv vmunagix vuibugae Muvgqhul gala: Gujisu tuluqhai jov bicigasu (HT1) jiv sudulul = "ProtoMongolian Language 1400 Years Ago. Studies of the Hüis Tolgoi Inscriptionn [sic!] (HT1)". Cologne: Elias Verlag Imo FiF e.V. 
Vovin, Alexander. 2017. Interpretation of the Hüis Tolgoi Inscription https://ehess .academia.edu/AlexanderVovin/Draft-Papers.

Vovin, Alexander. 2018. An Interpretation of the Khüis Tolgoi Inscription. Journal Asiatique 306 (2): 303-313.

Vovin, Alexander. 2019a. Groping in the Dark: the First Attempt to Interpret the Bugut Brāhmī Inscription. Journal Asiatique 307 (1): 121-134.

Vovin, Alexander. 2019b. A Sketch of the Earliest Mongolic Language: The Brāhmī Bugut and Khüis Tolgoi Inscriptions. International Journal of Eurasian Linguistics $1(1): 162-197$.

Vovin, Alexander. 2021 (forthcoming). The Directionality of the Earliest TurcoMongolian Language Contacts Revisited: The Data from Mongolic Brāhmī Bugut and Khüis Tolgoi Inscriptions. Harvard Journal of Turkish Studies, Festschrift for Marcel Erdal, ed. by Hatice Şirin. 